\title{
Анна СОБЧУК,
}

orcid.org/0000-0001-9278-9958

асистент кафедри початкової та дошкільної освіти Львівського національного університету імені Івана Франка (Львів, Украӥна) annychka79@ukr.net, anna.sobchuk@edu.lnu.ua

\section{ЗМІСТ ПРОФЕСІЙНОЇ ПІДГОТОВКИ МАЙБУТНІХ ВЧИТЕЛІВ ПОЧАТКОВОЇ ШКОЛИ В РЕСПУБЛІЦІ ПОЛЬЩА ДО РОБОТИ В УМОВАХ ІНКЛЮЗІЇ}

\begin{abstract}
У контексті євроінтеграційних процесів активно здійснюється реформування освітньої системи в Республіці Польща, щзо позначається на організаційних і змістових аспектах професійної підготовки майбутніх вчителів початкової школи. На сучасному етапі особливої актуальності набуває професійна підготовка майбутніх педагогів початкової школи до роботи в умовах інклюзії в закладах вищоӧ освіти Республіки Польща.

У статті проаналізовано змістовий компонент професійної підготовки майбутніх вчителів початкової школи до роботи в умовах інклюзії в закладах вищої освіти Республіки Польща. Професійна підготовка вчителів початкової школи в Польщі здійснюеться у формах стачіонарного, заочного, вечірнього чи екстернатного навчання; на рівнях бакалаврату («ліценціату») та магістратури; у державній і приватній системах.

Визначено, щьо однією з особливостей польського досвіду професійної підготовки майбутніх вчителів початкової школи є blended learning, яке передбачає поєднання онлайн- та офлайн-навчання. Аналіз силабусів, інклюзивно спрямованих курсів, дав підстави для висновку щцодо послідовності відбору й викладу навчального матеріалу з курсів інклюзивного спрямування від положень міжнародних і державних документів, які регулюють впровадження інклюзивної освіти, до організаційних, дидактичних і виховних засад інтегрованої та інклюзивної освіти в Республічі Польщиа, до діагностичного й методичного інструментарію, який дочільно використовувати в навчальному процесі, та особливостей роботи з різними категоріями учнів, які мають особливі потреби.

Автор статті охарактеризувала зміст навчальних дисциплін «Інтегрована та інклюзивна освіта на другому та третьому етапах освіти» ("Kształcenie integracyjne i edukacja wtączajaca na II $i$ III etapie kształcenia”) ma «Проектування інтегрованої та інклюзивної освіти» (“Projektowanie edukacji wtaczajacej i integracyjnej”) Університету імені Адама Міикевича в м. Познань (Uniwersytet im. Adama Mickiewicza w Роzпапіи), визначила недоліки в силабусах і викладанні вказаних дисииплін.
\end{abstract}

Ключові слова: заклад вищої освіти, інклюзія, навчальна дисципліна, силабус, вчителі початкової школи.

\author{
Anna SOBCHUK, \\ orcid.org/0000-0001-9278-9958 \\ Assistant at the Department of Primary and Preschool Education \\ Ivan Franko National University of Lviv \\ (Lviv,Ukraine)annychka79@ukr.net, anna.sobchuk@lnu.edu.ua
}

\section{CONTENT OF PROFESSIONAL TRAINING OF FUTURE PRIMARY SCHOOL TEACHERS IN THE REPUBLIC OF POLAND TO WORK IN CONDITIONS OF INCLUSION}

The article analyses the organizational and semantic aspects of professional training of future primary school teachers to work in the context of inclusion in higher educational institutions of the Republic of Poland. In the context of the study of organizational aspects, the author emphasizes that the professional training of primary school teachers in Poland is carried out in the form of full-time, distance, evening or external studies; at the bachelor's (licentiate's) and master's levels; in public and private systems. It was found that one of the features of the Polish experience of professional training of future primary school teachers is blended learning, which involves a combination of online and offline learning.

The author of the article described the content of the following academic subjects: Integrated and Inclusive Education in the Second and Third Stages of Education (Kształcenie integracyjne i edukacja właczajaca na II i III etapie ksztatcenia) and Design of Integrated and Inclusive Education (Projektowanie edukacji wtaczajacej i integracyjnej) of Adam Mickiewicz University of Poznan (bachelor's degree).

Based on the analysis of syllabuses of courses, the author described the informational volume of educational material and the logic of its presentation from the provisions of international and state documents governing the introduction of inclusive education, to organizational, didactic and educational principles of integrated and inclusive education in the Republic of Poland. Besides, the author covered methodological tools that should be used in the educational process, and features of working with different categories of students with special needs. 
The author of the article described the forms and methods of teaching, the format and methods of control. The analysis of references for the course gave the grounds to conclude that they need to be updated in accordance with the current development of science and supplemented by online sources. She identified shortcomings in the teaching of inclusiveoriented subjects, which included insufficient practical training of future primary school teachers, which negatively affects their professional activities.

Key words: academic subjects, higher educational institution, inclusion, primary school teachers, syllabus.

Постановка проблеми. В контексті євроінтеграційних процесів активно здійснюється реформування освітньої системи в Республіці Польща, що позначається на організаційних і змістових аспектах професійної підготовки майбутніх вчителів початкової школи. Оновлення змістового наповнення навчальних дисциплін насамперед передбачає впровадження нових підходів до формування змісту освіти: реалізацію європейських вимог до складання навчальних планів підготовки бакалаврів і магістрів - майбутніх вчителів початкової школи; забезпечення «вільної траєкторії» освітньої діяльності студента; урахування побажань студента щодо формування змістового і кредитного складників індивідуального навчального плану; гарантування високого рівня практичної підготовки фахівця.

Аналіз досліджень. На сучасному етапі особливої актуальності набуває професійна підготовка майбутніх педагогів початкової школи до роботи в умовах інклюзії в закладах вищої освіти Республіки Польща. До зазначеної проблеми дотично, в контексті професійно-педагогічної освіти, зверталися польські вчені M. Анджеєвська (М. Andrzejewska), К. Служевскі (K. Służewski), Г. Карваш (G. Karwasz), T. Менчиковська (Т. Męczykowska), М. Руштецька (M. Rusztecka), Х. Рокіта (K. Rokita), Ф. Женьковські (F. Zeńkowski), C. Мойхо (S. Мојсho). Однак поза увагою науковців залишаються змістові i процесуальні аспекти викладання інклюзивно орієнтованих курсів у межах професійної підготовки майбутніх вчителів початкової школи.

Мета статті - проаналізувати організаційні і змістові аспекти професійної підготовки майбутніх вчителів початкової школи до роботи в умовах інклюзії в закладах вищої освіти Республіки Польща. Досягнення зазначеної мети передбачало виконання таких дослідницьких завдань: визначити особливості організації підготовки вчителів початкових класів до роботи на засадах інклюзії; охарактеризувати зміст інклюзивно-орієнтованих навчальних дисциплін на основі аналізу силабусів.

Виклад основного матеріалу. Особливості організації підготовки вчителів початкових класів до роботи на засадах інклюзії. Основними тенденціями, відображеними в змісті професійної освіти майбутніх вчителів початкової школи Республіки Польща, є підтримка всебічного та гармонійного розвитку дитини, орієнтація на іiі потреби, інтеграцію в учнівський колектив і соціум загалом; спрямованість освіти та виховання на загальноєвропейські цінності й ідеали; підготовка майбутнього педагога до реалізації освітньо-виховних, корекційних, терапевтичних функцій; використання в освітній діяльності інноваційних та інформаційних технологій; налагодження співробітництва закладів освіти, сім'ї, психолого-педагогічних служб для ефективної роботи в інклюзивному середовищі, спрямованої на попередження агресії й насильства, булінгу в учнівському колективі, а також підтримка дітей, які мають особливі освітні потреби (Jedlewska, 2008).

Відносно новим напрямом у педагогіці $\epsilon$ інклюзивна освіта, яка актуалізує низку вимог не лише до держави, а й до вчителя, який має розуміти, що інклюзивна освіта базується на праві всіх учнів на якісну освіту, має задовольняти їхні основні потреби в навчанні, спрямовуватися на використання потенціалу кожної особистості; протидіяти усім формам дискримінації. Головне завдання підготовки вчителів початкових класів, залучених до створення інклюзії, за визначенням (DarlingHammond, 2019) полягає не лише в формуванні у вихованців з особливими потребами впевненості у власних можливостях, а й у розвитку їхньої здатності до позитивного самооцінювання.

Професійна підготовка вчителів загалом i початкової школи зокрема у Польщі здійснюється у двох юридично-адміністративних системах: публічній і непублічній (державній і приватній); у двох середовищах: академічному (університети, вищі професійні школи, вищі педагогічні школи) та освітньому (вчительські колегії, які мають статус вищих шкіл); на різних рівнях (бакалаврат (ліценціат) і магістратура); у різних формах: стаціонарній, заочній, вечірній (Кристопчук, 2013). Навчання на рівні «бакалавр» («ліценціат») триває щонайменше шість семестрів, до цього терміну входить також професійна практика. Навчання на другому ступені охоплює три або чотири семестри, тобто безперервне магістерське навчання продовжується від дев'яти до дванадцяти семестрів. При цьому навчання на заочній формі здебільшого триває на один або два семестри довше, ніж відповідне навчання на денній формі. 
Собчук А. Зміст професійної підготовки майьутніх вчителів початкової шкоми ...

У системі підготовки вчителів початкових класів до роботи на засадах інклюзії найбільш поширеними є стаціонарна та заочна форми навчання. Щоб здобути педагогічну освіту в умовах стаціонарної підготовки, у більшості закладів вищої освіти абітурієнт має довести, що він $є$ професійно придатним, склавши тест на професійні здібності й отримавши високі результати випускних іспитів (egzamin maturalny).

Студенти стаціонарної форми навчання здебільшого відвідують заняття 4-5 днів на тиждень. Один день, в основному п'ятниця, відводиться для індивідуального навчання. Денна форма здобуття вищої освіти передбачає безпосередню участь викладачів і студентів у заняттях, які складають не менше половини загального обсягу навчального часу (аудиторні години), передбаченого навчальними програмами.

Студенти заочної форми навчання відвідують заняття двічі на місяць (п'ятниця, субота, неділя). Вечірня форма навчання передбачає заняття 3 понеділка по п’ятницю 3 16:00. Особливості навчання на заочній і вечірній формах визначаються сенатом закладу вищої освіти. Студенти мають можливість скористатися й екстернатною формою навчання, проте для отримання дозволу на навчання за цією формою має бути поважна причина, підтверджена відповідними документами. Навчальний рік у межах екстернатної форми триває 10 місяців і складається з двох семестрів: зимовий (жовтень-лютий), літній (березень-липень),

Однією $з$ особливостей польського досвіду професійної підготовки майбутніх фахівців $\epsilon$ застосування елементів дистанційного навчання поряд із традиційним навчанням як допоміжного засобу підвищення ефективності освіти та стимулювання самостійного навчання. Найпоширенішою формою такого навчання $є$ blended learning чи nauczanie mieszane, тобто змішане навчання, яке передбачає поєднання онлайн- та офлайн-навчання: теоретичний матеріал, який майбутній вчитель початкового навчання опрацьовує онлайн (шляхом самостійного прочитання матеріалів, перегляду демонстраційних відео, відеозапису лекції викладача, участі в грі), згодом опрацьовується офлайн (під час занять у закладі вищої освіти). Це сприяє поглибленню, узагальненню, систематизації знань, з'ясуванню незрозумілих аспектів питання, а також формуванню практичних навичок і вмінь виконання практичних завдань. Поєднання самостійного онлайн навчання 3 консультативною підтримкою дає змогу майбутнім вчителям початкової школи не залишатися сам на сам із навчальним матеріалом й успішно опановувати інформаційний блок, вико- нувати практичні завдання, що є запорукою грунтовних теоретичних знань і сформованих навичок.

Аналіз навчальних планів польських закладів вищої освіти, які здійснюють підготовку майбутніх вчителів початкової школи, дав підстави для висновку, що професійна підготовка майбутніх вчителів молодших класів до роботи на засадах інклюзії $\epsilon$ тримодульною і містить: 1) спеціалізаційний компонент теоретичного та прикладного змісту; 2) педагогічно-психологічний компонент зі спрямуванням на вікові особливості дітей, специфіку порушень розвитку; 3) методологічно-дидактичний компонент. Передбачене і практичне навчання за модулями для застосування здобутих знань.

Зміст інклюзивно-оріснтовних курсів професійної підготовки майбутніх вчителів початкової школи. У процесі дослідження було проаналізовано силабуси навчальних дисциплін, які входять до навчальних планів підготовки бакалавра в Університеті імені Адама Міцкевича в м. Познань (Uniwersytet im. Adama Mickiewicza w Poznaniu). Так, предмет «Інтегрована та інклюзивна освіта на другому та третьому етапах освіти» ("Kształcenie integracyjne i edukacja włączająca na II i III etapie kształcenia", 2019) студенти опановують на другому курсі. В анотації зазначено, що передумовами для здобуття майбутніми вчителями знань, умінь і навичок $є$ розуміння загальних тенденцій у системі освіти загалом і педагогічному процесі закладів середньої освіти зокрема, тобто студенти повинні мати базові знання з педагогіки. Цей курс передбачає ознайомлення майбутнього вчителя із загальними тенденціями і процесами в спеціальній освіті в контексті інтегрованої та інклюзивної освіти, зокрема увагу акцентовано на організації дидактичної, навчальної й терапевтичної діяльності в предметному навчанні початкової школи та на гімназійному етапі.

Серед цілей опанування зазначеної навчальної дисципліни вказано такі: ознайомлення майбутніх вчителів із правовими основами та положеннями, які випливають 3 міжнародних резолюцій, ратифікованих Польщею, щодо навчання учнів в системі загальної та інклюзивної освіти; характеристика теоретичних основ інклюзивної та інтегрованої освіти; аналіз основних термінів і понять, пов'язаних із цими видами освіти; диференціація понять у контексті потреб і можливостей учнів з особливими потребами; ознайомлення зі специфікою інтегрованої й інклюзивної освіти в контексті учнівських потреб і їхньої здатності до виконання навчальних завдань; визначення шляхів соціального прийняття учня 3 особливими потребами в групі однолітків інтегрованого чи інклюзивного класу. 
Змістовий обсяг дисципліни охоплює такі теми: «Парадигмальні зміни в педагогіці та спеціальній педагогіці як основа для розроблення концепції інтегрованої та інклюзивної освіти»; «Інтегрована та інклюзивна освіта в системі польської освіти»; «Характеристика інтегрованої освіти: правові й організаційні аспекти»; «Характеристика інклюзивної освіти: юридичні й організаційні аспекти»; «Інтегрована та інклюзивна освіта: проблема дефініцій і навчальні завдання»; «Умови реалізації ідеї інтегрованої та інклюзивної освіти: організація освітнього процесу, інституційна інфраструктура»; «Ставлення суспільства до інклюзивної освіти: позиція батьків, учнів, вчителів»; «Компетенції вчителів щодо роботи з учнями $з$ особливими потребами в інклюзивній освіті. Проблеми підтримки учнів з обмеженими можливостями в інтегрованій та інклюзивній освіті: кваліфікація вчителів, співпраця 3 фахівцями»; «Проектування навчально-виховної діяльності для роботи в класах 3 інклюзією». Тому можна дійти висновку, що виклад навчального матеріалу здійснюється за такою схемою: від аналізу наукових тенденцій і процесів через організаційні аспекти до їх практичного втілення.

У силабусі навчального курсу «Інтегрована та інклюзивна освіта на другому та третьому етапах освіти» чітко визначені результати навчальної діяльності після опанування предмета та підсумкового контролю: студент має комплексні знання про структуру та функції системи освіти людей 3 особливими потребами; знає особливості навчання цієї категорії учнів на другому та третьому етапах освіти відповідно до різних форм іiї організації; володіє знаннями про освітні системи інших країн; орієнтується в соціальних явищах, які впливають на освітній процес; уміє використовувати та інтегрувати теоретичні знання в галузі спеціальної освіти та суміжних дисциплін для аналізу складних навчальних, виховних, культурних і терапевтичних проблем, а також для діагностування й проектування практичної діяльності; уміє обирати й ефективно застосовувати теоретичні підходи та практичні дії для ефективної роботи 3 дітьми 3 особливими потребами. Наголошено, що в майбутнього вчителя необхідно виховати чутливість до освітніх проблем, він має демонструвати готовність спілкуватися та співпрацювати 3 іншими людьми, зокрема 3 фахівцями у зазначеній і дотичних галузях, а також брати активну участь у роботі груп та організацій, які здійснюють педагогічну діяльність 3 учнями 3 особливими потребами.

У межах зазначеного курсу передбачено лише лекційні заняття, під час яких використовуються такі методи навчання як студентські проекти, лек- ції, ілюстративні методи. У навчально-методичному забезпеченні курсу чітко прописані критерії оцінювання роботи студентів, зокрема вказано такі види навчальної діяльності: підготовка до участі в лекціях; опрацювання запропонованої літератури; вміння висловлювати й відстоювати власну думку, вміння аналізувати й синтезувати матеріал курсу, коригувати власні ідеї.

У процесі опанування зазначеного курсу студенти мають скласти колоквіум, а також письмовий тест, який складається із 50\% закритих, що оцінюються в 0-1 бал, і 50\% відкритих, які оцінюються в 0-2 бали, запитань. Для того, щоб скласти тест на мінімальну позитивну оцінку, студент має дати 70\% правильних відповідей. Загалом його результати оцінюються за такою схемою: 71-75\% правильних відповідей - це «задовільно», 76-80\% - «задовільно плюс», 81-86\% - «добре», 87-94\% - «добре плюс», 95-100\% - «дуже добре».

$\mathrm{У}$ навчальній програмі вміщено значний за обсягом список літератури до курсу, серед якої міжнародні й державні документи, які регулюють впровадження інклюзивної освіти, а також монографії і публікації науковців. Проведений аналіз дав підстави для висновку, що цей перелік потребує оновлення, оскільки програма розрахована на зимовий семестр 2019-2020 н.р., а останні видання датуються 2004 роком, більшість їх стосується кінця 1990-х років - початку 2000 -х років. Вважаємо ці видання такими, що не відповідають сучасному рівню розвитку педагогічної науки, оскільки сфера інклюзивної освіти нині стрімко розвивається і за попередні десятиліття в ній з'явилася велика кількість досліджень теоретичного і практичного характеру, які доцільно використовувати в освітньому процесі.

У цьому університеті для майбутніх вчителів запропоновано ще один інклюзивно-орієнтований курс - «Проектування інтегрованої та інклюзивної освіти» ("Projektowanie edukacji włączającej i integracyjnej”, 2019). Предмет викладається на другому курсі бакалаврату, входить до інваріантного складника навчального плану загальним обсягом 4 кредити ECTS, у межах яких заплановано 30 годин лекційних, під час яких студенти мають критично проаналізувати поняття інтегрованої та інклюзивної освіти та особливості дизайну класів для інтегрованих груп. Підсумкова оцінка за курс виставляється на основі оцінювання студентського проекту та іспиту.

В анотації визначено навчальні цілі дисципліни: розвиток навичок критичного порівняльного аналізу понять «сегрегація», «інтеграція», «інклюзія»; ознайомлення з концепцією інклюзивної освіти, зокрема іiі правовими, психологічними, 
соціальними аспектами; розвиток у майбутніх вчителів здатності критично розмірковувати над рівними освітніми можливостями для всіх учнів, а також організаційними, правовими та соціальними бар'єрами у процесі соціальної інтеграції; ознайомлення зі стратегіями інклюзивної освіти в закладах середньої освіти (створення середовища, сприятливого для інклюзивного й інтегрованого навчання, організація роботи в інтегрованому чи інклюзивному класі, розроблення програм і планів занять з урахуванням потреб таких класів, розвиток умінь роботи в таких класах).

У результаті опанування навчального курсу майбутні вчителі мають знати поняття «сегрегації», «інтеграції», «інклюзії»; розуміти відмінності між сегрегаційною, інтегрованою та інклюзивною освітою й їхніми результатами для особистості; орієнтуватися в правових аспектах інклюзивної та інтегративної освіти в Польщі; висловлювати свою думку щодо проблеми рівних освітніх можливостей для всіх дітей і обгрунтовувати іï; визначати і характеризувати правові і соціальні бар'єри у процесі соціальної та освітньої інтеграції, формулювати стратегічні висновки для практичної діяльності; критично аналізувати стратегії інклюзивної освіти в закладах середньої освіти в межах тем про створення інклюзивноорієнтованого середовища в закладах середньої освіти, організацію роботи в інклюзивному класі, розроблення програм і планів занять 3 урахуванням потреб учнів класу, проводити заняття для класів 3 інклюзією та інтеграцією; використовувати літературу із зазначеної теми.

Логіка опанування навчального матеріалу така: від ознайомлення з теоретичними аспектами проблеми до формулювання практичних висновків $\mathrm{i}$ рекомендацій. На нашу думку, більшої ефективності освітнього процесу можна було б досягнути, розглядаючи різні аспекти практичної діяльності вчителя початкової школи в інклюзивно-орієнтованому середовищі закладу середньої освіти під час практичних занять.

Варто зазначити, що перелік літератури до курсу значно коротший, порівняно з попереднім, проте більш сучасний, оскільки містить видання здебільшого 2000-х років, останні 3 яких датовані 2014 роком. Важливо, що до цього переліку увійшли і онлайн джерела, проте лише дві позиції. На нашу думку, їхній перелік потрібно розширити, що сприятиме глибшому опануванню курсу майбутніми вчителями початкової школи.

Аналіз силабусів навчальних дисциплін і наукових праць із проблеми дослідження дає підстави для висновку, що недоліком професійної підготовки майбутніх вчителів початкової школи є недостатній рівень практичної підготовки майбутніх вчителів початкової школи до роботи в умовах інклюзії: студенти, які закінчили трирічне навчання на рівні ліценціату, здобувають необхідний обсяг теоретичних знань у галузі соціальної і спеціальної педагогіки, педагогічної і соціальної психології. Водночас спостерігається недостатня сформованість освітніх та організаційних умінь і навичок роботи в умовах інклюзії, неготовність до розв'язання професійних завдань і ситуацій, нездатність враховувати індивідуальні фізичні, психологічні й розумові особливості учнів.

M. Пивоварчук наголошує, що викладачі педагогічних факультетів закладів вищої освіти не проводять регулярних занять у школах, а тому не можуть на достатньому рівні ознайомити студентів зі шкільною практикою, 3 реальними проблемами в педагогічній діяльності вчителя загалом і в роботі $з$ дітьми з особливими потребами зокрема. Тому у вчителів початкових класів виникають проблеми 3 використанням досягнень сучасної соціальної і спеціальної педагогіки й психології; співпрацею 3 іншими фахівцями, органами шкільного самоврядування; організацією позакласного навчання та позашкільної діяльності учнів; налагодженням співробітництва 3 батьками учнів з особливими потребами; визначенням цілей освіти та здатності керувати процесом їхнього досягнення; плануванням занять iз використанням інтеграції, їхнім аналізом та об'єктивним оцінюванням результатів навчання учнів і власної роботи; адаптацією змісту, методів і форм навчання до навчальних ситуацій, які постійно змінюються; індивідуалізацією навчально-виховного процесу; складанням форми оцінювання навчального прогресу окремих учнів; забезпеченням ефективної допомоги учням, які мають проблеми з успішністю чи дисципліною.

Висновки. У результаті дослідження організаційних аспектів з'ясовано, що професійна підготовка вчителів початкової школи в Польщі здійснюється у формах стаціонарного, заочного, вечірнього чи екстернатного навчання; на рівнях бакалаврату («ліценціату») та магістратури; у державній і приватній системах. Визначено, що однією з особливостей польського досвіду професійної підготовки майбутніх вчителів початкової школи є blended learning, яке передбачає поєднання онлайн- та офлайн-навчання.

Аналіз силабусів інклюзивно спрямованих курсів дав підстави для висновку щодо послідовності відбору й викладу навчального матеріалу 3 курсів інклюзивного спрямування від положень 
міжнародних і державних документів, які регулюють впровадження інклюзивної освіти, до організаційних, дидактичних і виховних засад інтегрованої й інклюзивної освіти в Республіці Польща, до діагностичного й методичного інструментарію, який доцільно використовувати в навчальному процесі, та особливостей роботи з різними категоріями учнів, які мають особливі потреби.

Визначено, що вказані курси здебільшого мають теоретичний характер, сприяють опануванню студентами знань із соціальної і спеціальної педагогіки, педагогічної і соціальної пси- хології, однак характеризуються недостатньою увагою до формування практичних вмінь і навичок роботи в умовах інклюзії. Тому майбутні вчителі початкової школи виявляються не готовими до розв'язання професійних завдань і ситуацій, нездатними враховувати індивідуальні фізичні, психологічні й розумові особливості учнів.

Перспективи подальших досліджень вбачаємо у визначенні шляхів імплементації польського досвіду професійної підготовки майбутніх вчителів початкової школи в роботу українських закладів вищої освіти.

\section{СПИСОК ВИКОРИСТАНИХ ДЖЕРЕЛ}

1. Кристопчук Т. Педагогічна освіта в Республіці Польща: структура та зміст. Неперервна професійна освіта: теорія і практика. 2013. Вип. 3-4. С. 127-134.

2. Пивоварчук М. Підготовка фахівців за спеціальностями напряму «Педагогіка» у Вроцлавському університеті. Педагогічна освіта і наука в умовах класичного університету: традииї, проблеми, перспективи: у 3 т. Т. 1. Львів : ЛНУ імені Івана Франка, 2013. С. 100-120.

3. Darling-Hammond L., Flook L., Cook-Harvey C., Barron B. \& Osher D. (2019). Implications for educational practice of the science of learning and development, Applied Developmental Science. DOI: 10.1080/10888691.2018.1537791.

4. Jedlewska B. Miejsce i ranga animacji spoleczno-kulturalnej w educacji pedagogow w Polskish Uniwersytetah. Пeдaгогічна освіта в Україні і Польщі: реалії та перспективи : зб. наук. пращь. Львів : Видавничий центр Львівського національного університету ім. І. Франка «Тріада плюс», 2008. С. 271-290.

5. Kształcenie integracyjne i edukacja włączająca na II i III etapie kształcenia. Uniwersytet im. Adama Mickiewicza w Poznaniu. URL: https://usosweb.amu.edu.pl/kontroler.php?_action=katalog2/przedmioty/pokazPrzedmiot\&kod=11-KI-11-s (дата звернення: 03.03.2020).

6. Projektowanie edukacji włączającej i integracyjnej. Uniwersytet im. Adama Mickiewicza w Poznaniu. URL: https://ects.amu.edu.pl/pl/courses/view?prz_kod=11-PE-5TER-s (дата звернення: 05.03.2020).

\section{REFERENCES}

1. Krystopchuk T. Pedahohichna osvita v Respublitsi Polshcha: struktura ta zmist [Pedagogical education in the Republic of Poland: structure and context]. Neperervna profesiina osvita: teoriia i praktyka. [Continuing professional education: theory and practice]. 2013. Vol. 3-4. P. 127-134 [in Ukrainian].

2. Pivovarchuk M. [Training of specialists in the specialties of "Pedagogy" at the University of Wroclaw]. Pedahohichna osvita i nauka v umovakh klasychnoho universytetu: tradytsii, problemy, perspektyvy [Pedagogical education and science in the conditions of classical university: traditions, problems, prospects: in 3 vols.]. Lviv : Ivan Franko National University of Lviv, 2013. Vol. 1. P. 100-120 [in Ukrainian].

3. Darling-Hammond L., Flook L., Cook-Harvey C., Barron B. \& Osher D. Implications for educational practice of the science of learning and development. Applied Developmental Science. 2019. Doi: 10.1080/10888691.2018.1537791.

4. Jedlewska B. Miejsce i ranga animacji spoleczno-kulturalnej w educacji pedagogow w Polskish Uniwersytetah. [The place and importance of social and cultural animation in educating teachers at the Polish University]. Pedahohichna osvita v Ukraini i Polshchi: realii ta perspektyvy : zb. nauk.prats [Pedagogical education in Ukraine and Poland: realities and prospects: collection. science wash]. Lviv : Lviv National University Publishing Center. I. Franko's "Triad Plus”, 2008. S. 271-290 [in Polish].

5. Kształcenie integracyjne i edukacja włączająca na II i III etapie kształcenia. Uniwersytet im. Adama Mickiewicza w Poznaniu. [Integrative education and inclusive education at the second and third stages of education. University of Adam Mickiewicz in Poznań]. Retrieved from: https://usosweb.amu.edu.pl/kontroler.php?_action=katalog2/przedmioty/pokazPrzedmiot\&kod=11-KI-11-s (Last accessed: 20.03.2020) [in Polish].

6. Projektowanie edukacji włączającej i integracyjnej. Uniwersytet im. Adama Mickiewicza w Poznaniu. [Designing inclusive and inclusive education. University of Adam Mickiewicz in Poznań]. Retrieved from: https://ects.amu.edu.pl/pl/ courses/view?prz_kod=11-PE-5TER-s (Last accessed: 20.03.2020) [in Polish]. 